\title{
Impact of Microfinance on Women Empowerment: An Empirical Evidence from Andhra Pradesh
}

Sujatha Gangadhar $\mathbf{C H}^{1 *}$ and Malyadri $\mathbf{P}^{2}$

${ }^{1}$ Jawaharlal Nehru Institute of Advanced Studies (JNIAS), Telangana School of Management and Training, Secunderabad, Telangana, India

${ }^{2}$ Principal, Government Degree College, Osmania University, Patancheru, Hyderabad, Telangana, India

\begin{abstract}
This paper makes an attempt to evaluate the effectiveness of microfinance on empowerment of women. A crosssectional research on 215 women in the State of Andhra Pradesh, India through a structured questionnaire was conducted. Population of study is women who are associated with Self Help Groups (SHG's). These women are married and have at least one child. Exploratory factor analysis is used to study the indicators of women empowerment. Results reveal that indicators of women empowerment are household economic decision making, legal awareness, mobility, economic security and family decision making. Five hypotheses are developed to evaluate the effectiveness of microfinance on empowerment of women for mentioned five indicators. Paired samples $t$ test is used to know the difference in women's perception before joining microfinance program and after joining microfinance program. The findings of this study reveal that microfinance is a powerful tool in enhancing women empowerment for its all indicators like household economic decision making, legal awareness, mobility, economic security and family decision making.
\end{abstract}

Keywords: Microfinance; Women empowerment; Self-Help Group; Economic security; Household economic decision making

\section{Introduction}

Empowering women is a vital tool for alleviating poverty. Empowered women contribute to the health and productivity of whole families and communities and to improved prospects for the next generation [1]. There have been several institutions advocating for women empowerment, but women are still poor and vulnerable as compared to men. The main reasons for the same are economic dependence on male members, rapid increase in population, unemployment, illiteracy and lack of access to credit. Rural women play a significant role in the domestic and socio-economic life of the society and therefore, national development is not possible without developing this segment of the society [2]. For the development of poor women it is essential to improve their economic and social status. When their economic, cultural and social status improves, it is known as women empowerment [3].

Microfinance has emerged as a powerful tool for women empowerment in the new economy. In India, microfinance distribution is mainly dominated by Self Help Groups (SHGs) -Bank Linkage Programme. It aims at providing a cost effective mechanism for providing financial services to the poor section of the society.

Efforts on women empowerment will help society to get rid of social evils. There is a long way to take people away from poverty but SHGs can become significant tool to achieve this objective through microfinance programs. According to Mukherjee and Purkayastha [4], SHGs are the most contemporary modes for poverty eradication and women empowerment in India. Microfinance helps poor people including women in getting employment, increasing confidence, enhancing communication skills and in other aspects as well. Women gain greater control over resources like material possession, intellectual resources like knowledge, information, ideas and decision making at home, community, society and nation through involvement in these microfinance programs [3].

\section{Objectives of the Study}

With this backdrop, the main objectives of this study are
- To study the indicators of women empowerment.

- To evaluate the effectiveness of microfinance on empowerment of women.

Primary data is collected through a structured questionnaire from 215 women who are associated with SHGs in the State of Andhra Pradesh.

The research paper is organized as follows. The second section gives a brief overview of the literature followed by research methodology section. The fourth section presents the results and discussion. Under the fifth section, conclusion and limitations are described.

\section{Literature Review}

\section{Empowerment}

Empowerment is authorizing someone to exercise some specific power or offering someone certain means to achieve a given end [5] Empowerment, as defined by Kabeer [6] is the process by which those who lack the ability to make strategic life choices previously acquire such ability. Banu et al. [7] defined women's empowerment as the capacity of women in reducing their socio-economic vulnerability and dependency on male household members, improving involvement and control over household decisions, economic activities and resources, contribution to household expenses, increased self confidence and awareness of social issues.

\section{Microfinance}

Microfinance is "the provision of financial services to poor and

*Corresponding author: Sujatha Gangadhar $\mathrm{CH}$, Jawaharlal Nehru Institute of Advanced Studies (JNIAS), Secunderabad, India, Tel: 91-9848343635; E-mail: sujathagangadhar@gmail.com

Recieved June 09, 2015; Accepted June 30, 2015; Published July 08, 2015

Citation: Sujatha Gangadhar $\mathrm{CH}$, Malyadri P (2015) Impact of Microfinance on Women Empowerment: An Empirical Evidence from Andhra Pradesh. J Entrepren Organiz Manag 4: 141. doi:10.4172/2169-026X.1000141

Copyright: (c) 2015 Sujatha Gangadhar $\mathrm{CH}$, et al. This is an open-access article distributed under the terms of the Creative Commons Attribution License, which permits unrestricted use, distribution, and reproduction in any medium, provided the original author and source are credited. 
very poor self-employed people" [8]. Schreiner and Colombet [9] define microfinance as "the attempt to improve access to small deposits and small loans for poor households neglected by banks". Therefore, the purpose of microfinance is to raise the income of poor people by providing financial services or products of very small amount. These financial services are not limited to savings and credit but can also embrace other financial services such as insurance and payment services [10]. When poor people are unable to obtain financial services from banks directly then microfinance plays an important role in providing financial services. According to Robinson [11] microfinance helps poor people to increase, protect and diversify their income, as well as to accumulate assets, reducing their vulnerability to income and consumption shocks.

\section{Microfinance and women empowerment}

Goetz and Sen Gupta [12] made qualitative and quantitative analysis to examine the empowerment in the context of the household decision-making process. Their index of 'Managerial Control' classified the borrowers into five categories ranging from no control to full control on the use of the loans. Another study by Hashemi et al. [13] designed an 'empowerment index' to measure the impact of microcredit on women's empowerment. They used eight empowerment indicators, namely mobility, economic security, ability to make small purchases, ability to make larger purchases, involvement in major decisions, participation in public protests and political campaigning, relative freedom from family domination and political and legal awareness. Findings revealed that woman contributing to her household's income is a significant contributing factor towards her empowerment. Sarumathi and Mohan [14] used psychological, social, economic indicators to examine the role of microfinance in empowerment in Pondicherry region. Findings of the study revealed that microfinance assisted women in gaining psychological and social empowerment than economic empowerment. Several studies have concluded that microfinance helps bring poor people out of poverty, although, all microfinance programs are not equally proficient $[15,16]$. The study of Malathi and Vijayarani [17] examined the relationship between microfinance and women empowerment in rural areas of Cuddalore district of Tamil Nadu in India. Chi-square and t-test were performed to analyze the data using 100 sample sizes. Findings of this study revealed that microfinance help women in gaining empowerment. Empowerment is judged on the basis of economic position before and after joining the SHG program and education respectively.

The major focus of microfinance programs is to empower women as they are the most vulnerable and investing in women helps empowering them and contributes to greater economic growth and development. It is revealed in literature that increase in women's resources results in the well-being of the family [6]. Impact of microfinance on empowerment of women has given mixed results. According to Le and Raven [18], microfinance has helped many women in their businesses, but has a limited effect on empowering women, creating upward mobility and contributing to long-term economic growth. In Indian context, microfinance was found to have a positive influence on women's social capital and normative influence, facilitating women's collective empowerment [19]. According to Hussain and Nargis [20] the longer a woman participates in microcredit programs, the more employment opportunities she has. Further there is more scope that she may decide to buy productive and non-productive assets. A study conducted in Kenya by Holvoet [21] found that when loans are combined with more investment in social intermediation, remarkable shifts in decisionmaking patterns are visible. Another study by Naved [22] showed that women were more active in household decision making and had more control over household income after participating in microcredit programs. Moreover, participation in microcredit programs helps to increase women's welfare and reduce male bias [23].

Aruna and Jyothirmayi [24] examined the influence of microfinance on women empowerment through regression analysis in Hyderabad, India. Results revealed that microfinance had significant influence on socio-economic indicators. These indicators are considered as economic position, decision making power, knowledge and self worthiness.

Sultana and Hasan [25] conducted a study to know the impact of micro-credit on economic empowerment of rural women at Gazipur district in Bangladesh using stratified random sampling technique. The half sample study of (45 women) had involvement with microcredit program and rest half had no involvement with any other form of micro-credit program. These both groups belonged to the same socio-demographic profile. The study collected data on women empowerment considering three economic indicators namely personal income, savings behavior and asset ownership. Results revealed that women involved with micro-credit program were more benefited than the control group.

According to Moyle et al. [26], women in income generating activities give support to personal and economic empowerment. Another study conducted by Nader [27] found that microcredit improved health and harmony in the family. Pitt et al. [28] found that participation in microcredit programs help women to have access to financial and economic resources, significant role in household decision making, have greater social networks, have greater communication in general and knowledge about family planning and parenting concerns and have greater freedom of mobility.

On the basis of the above discussion, following hypotheses is proposed for the study:

\section{H1: Participation in micro-financing program improves women empowerment}

It is difficult to study women empowerment without considering the indicators. Empowerment indicators used in recent studies are shown in Table 1.

Since different authors have used different indicators to measure women empowerment, this study uses five indicators for measuring women empowerment. These indicators are economic security, household economic decision making, legal awareness, mobility and family decision making. Based on these indicators following hypotheses are proposed for study:

$H_{1}$-a: Participation in micro-financing program improves economic security.

$H_{1}-b$ : Participation in micro-financing program improves household economic decision making.

$H_{-}-c$ : Participation in micro-financing program improves legal awareness.

$H_{1}$-d: Participation in micro-financing program improves mobility.

$\mathrm{H}_{1}$-e: Participation in micro-financing program improves family decision making.

\section{Research Methodology}

A stratified multi stage sampling technique is used for the purpose of the study. The primary data is collected from 270 SHG 


\begin{tabular}{|c|c|}
\hline Dimensions & Author(s) \\
\hline $\begin{array}{l}\text { Household economic decision making, Economic } \\
\text { security, Women's control over resources, women's } \\
\text { control over family decisions, mobility and legal } \\
\text { awareness }\end{array}$ & Al-Mamun et al. [29] \\
\hline $\begin{array}{l}\text { Economic, autonomy, social attitudes, education } \\
\text { and network, communication and political } \\
\text { participation level. }\end{array}$ & Swain and Wallentin [30] \\
\hline Economic & Malathi and Vijayarani [17] \\
\hline $\begin{array}{l}\text { Socio-economic dimensions such as, economic } \\
\text { position, decision making power, knowledge and } \\
\text { self- worthiness }\end{array}$ & Aruna and Jyothirmayi [24] \\
\hline Psychological, social and economical & Sarumathi and Mohan [14] \\
\hline $\begin{array}{l}\text { Three economic indicators (personal income, } \\
\text { savings behavior and asset ownership) }\end{array}$ & Sultana and Hasan [25] \\
\hline
\end{tabular}

Table 1: Empowerment indicators used in recent studies.

women members in Andhra Pradesh, India through a well structured questionnaire by face to face interview. Survey instruments were administered personally and 270 women were contacted. Out of these 270 questionnaires, 55 were rejected because of missing data or high response bias leaving an overall sample size of 215 .

Selection of districts: Andhra Pradesh is a state of regional dimensions, there is a marked difference between the regions in terms of socio, economic and cultural aspects. Based on these aspects, the study area is divided into two zones. In the first stage, one district is selected based on prevalence of highest number of the SHGs from each zone. Accordingly, East Godavari district representing Coastal Andhra region and Chittoor district representing Rayalaseema region are selected for the present study.

Selection of mandals and villages: In the second stage, three mandals are selected from each district and three villages from each mandal on a random basis.

Selection of SHGs: In the third stage, three SHGs were selected from each village based on convenience sampling.

Selection of women: In the fourth and final stage; five women were selected from each SHG so that the total number of women is around 270 from 54 SHGs.

\section{Measurement}

The survey instrument included 15 items that assessed the women empowerment. This scale is adapted from two scales developed by Al-Mamun et al. [29] and Swain and Wallentin [30]. Swain and Wallentin [30] used five latent factors which encompasses economic position, autonomy, social attitudes, education and finally network, communication and political participation level. These latent factors are measured by a set of observed ordinal variables. Al-Mamun et al. [29] developed women's empowerment index using six indicators. These indicators are women's household economic decision making, economic security, women's control over resources, and women's control over family decisions, mobility and legal awareness. Based on the above, present study uses five indicators for measuring women empowerment. These indicators are Economic Security (ES), Household Economic Decision Making (HED), Legal Awareness (LA), Mobility (M) and Family Decision Making (FD). All items are measured using 3 point likert scale from disagree to agree.

\section{Economic Security (ES)}

It is measured through three items:
- ES 1 - I have independent savings;

- ES2 - I am confident to face financial crisis;

- ES 3 - I have assets like house/land/livestock in my name.

\section{Household Economic Decision Making (HED)}

It is measured through four items.

- HED 4 - I am involved in decision making related to improvement in home;

- HED 5 - I am involved in decision making related to household expenses;

- HED 6 - I am involved in decision making related to large purchases;

- HED 7 - I can buy clothes or other essentials for myself without permission of my husband.

\section{Legal Awareness (LA)}

It is measured through three items.

- LA 8 - I know that women have reservations in panchayats and jobs;

- LA 9 - I know that in case of abuse or violence, I can seek legal protection;

- LA 10 - I know that I can legally divorce my husband, if necessary.

\section{Mobility (M)}

It is measured through three items.

- M 11 - I can go outside the home alone;

- M 12 - I do not seek husband's permission before going out;

- M 13 - I can travel to nearby villages alone.

\section{Family Decision Making (FD)}

It is measured through two items.

- FD 14 - I am involved in decision regarding children' education/ marriage/career;

- FD 15 - I can discuss regarding birth control methods.

The administered questionnaire had 30 questions divided into two sections of 15 each representing pre-loan and post-loan scenario. All respondents are married women having at least one child.

\section{Results and Discussion}

The responses obtained were analyzed using SPSS. Factor analysis and Paired samples $t$ test are used for the analysis.

\section{Factor analysis results}

Construct validity: Construct validity (convergent and discriminant) is checked through exploratory factor analysis. High loading on one factor and no cross loading reveal convergent and discriminant validity respectively. Factor analysis is performed on 15 items scale of women empowerment. The factor analysis was done using principal component with an initial setting for Eigen values greater than 1.0. Orthogonal rotation (Varimax) is applied to reduce potential multi-co linearity among the items. Kaiser-Meyer-Olkin (KMO) and Bartlett's test results are shown in Table 2. 
As, the KMO value is greater than 0.5 and the significance level for Bartlett's test value is 0.000 which shows that the value is significant at 1 per cent level of significance, therefore it is appropriate to apply factor analysis.

Factor analysis result of women empowerment is shown in Table 3. The first factor 'Household Economic Decision Making (HED)' comprised four items and explained $20.57 \%$ of the total variance. This factor had an Eigen value of 3.7. The items, HED7, HED4, HED5 and HED6 are loaded on this factor.

The second factor 'Legal Awareness (LA)' comprised three items and explained $16.43 \%$ of the total variance. This factor had an Eigen value of 2.6. The items, LA8, LA9 and LA10 are loaded on this factor.

The third factor 'Mobility (M)' comprised three items and explained $13.37 \%$ of the total variance. This factor had an Eigen value of 1.8 . The items, M11, M13 and M12 are loaded on this factor.

The fourth factor 'Economic Security (ES)' comprised three items and explained $13.01 \%$ of the total variance. This factor had an Eigen value of 1.4. The items, ES2, ES1 and ES3 are loaded on this factor.

The fifth factor 'Family Decision Making (FD)' comprised two items and explained $9.94 \%$ of the total variance. This factor had an Eigen value of 1.2. The items, FD14 and FD15 are loaded on this factor.

Reliability: To establish internal consistency, Cronbach's alpha value for reliability was calculated. All values were above 0.60 , which may be considered as reliable. Value of Cronbach alpha is shown in Table 4.

Paired Samples $\mathbf{t}$ test: Paired sample $\mathrm{t}$ test analysis was done to investigate the significant difference between women perception regarding empowerment in pre and post microfinance intervention. Microfinance intervention will be considered effective if women perception score regarding empowerment after participation in microfinance program is found to be more than women perception score before participation in microfinance program.

Paired samples $t$ test results for Family Decision Making (FD): Paired sample $t$ test results for factor 'Family Decision Making (FD)' are shown in Tables 5 and 6. To have more clarity, test is used for all items along with factor. The paired sample $t$ test analysis indicates that for item FD14, the mean score of women perception after participation in microfinance program $(M=2.23)$ was significantly greater than the mean score before participation in microfinance program $(\mathrm{M}=1.73)$ at $1 \%$ significant level. For item FD15, the mean score for women perception after participation in microfinance program $(M=2.37)$ was significantly greater than the mean score before participation in microfinance program $(\mathrm{M}=2.16)$ at $1 \%$ significant level.

For factor 'Family Decision Making' the mean score for women perception after participation in microfinance program $(\mathrm{M}=2.30)$ was significantly greater than the mean score before participation in microfinance program $(\mathrm{M}=1.94)$ at $1 \%$ significant level. Therefore, hypothesis "participation in micro-financing program improves Family Decision Making" is selected at $1 \%$ significant level. This finding is consistent with previous research findings. A study conducted by Pitt et al. [28] found that participation in microcredit programs help women in household decision making including greater communication in general about family planning and parenting concerns. Another study by Naved [22] also indicated that women were more active in household decision making after participating in microcredit programs. When women start participating in microfinance programs they get exposure to a new world that facilitates their decision making. They become more confident in expressing their views when they attend different programs. This is supported by a study conducted by Holvoet [21]. According to him when loans are combined with more investment in social intermediation, remarkable shifts in decision-making take place.

Paired samples $t$ test results for Economic Security (ES): Paired sample $t$ test results for factor 'Economic Security' are shown in Tables 7 and 8 . The paired sample $t$ test analysis indicates that for item ES1, the mean score of women perception after participation in microfinance program $(M=2.43)$ was not significantly greater than the mean score before participation in microfinance program $(\mathrm{M}=2.41)$ at $5 \%$ significant level. For item ES2, the mean score for women perception after participation in microfinance program $(\mathrm{M}=2.33)$ was significantly greater than the mean score before participation in microfinance program $(\mathrm{M}=1.98)$ at $1 \%$ significant level. For item ES3, the mean score for women perception after participation in microfinance program $(M=2.45)$ was significantly greater than the mean score before participation in microfinance program $(\mathrm{M}=2.00)$ at $1 \%$ significant level.

For factor 'Economic Security' the mean score for women perception after participation in microfinance program $(\mathrm{M}=2.40)$ was significantly greater than the mean score before participation in microfinance program $(\mathrm{M}=2.12)$ at $1 \%$ significant level. Therefore, our hypothesis that "participation in micro-financing program improves economic security" is selected at $1 \%$ significant level. For item 'ES1' hypothesis is not selected but for 'ES2' and 'ES3' hypotheses are selected. Women have not found any change in their saving after participation in micro-financing program. Here the reason may be increase in their expenditure after participation in the micro-financing program. This finding is supported by study of Al-Mamun et al. [29], wherein the respondents reported that their level of contribution to family expenses increased after participation in microcredit program. As women start earning, standard of living increases and it leads to more spending. Findings revealed that women are found confident in facing financial crisis and arranging crisis on time. These results are in congruence with previous findings. Aruna and Jyothirmayi [24] revealed that microfinance had significant influence on economic position. Moyle et al. [26] found that women in income generating activities give support to economic empowerment. Though our study has not considered economic position as indicator of women empowerment but economic security also develops from better economic position. Sultana and Hasan [25] also revealed that women involved with micro-credit program had better economic position than those women who were not linked to any program.

Paired Samples $t$ test results for Legal Awareness (LA): Paired sample $t$ test results for factor 'Legal Awareness' are shown in Tables 9 and 10. The paired sample t test analysis indicates that for item LA8, the mean score of women perception after participation in microfinance program $(M=2.15)$ was significantly greater than the mean score before participation in microfinance program $(M=1.93)$ at $1 \%$ significant level. For item LA9, the mean score for women perception after participation in microfinance program $(M=2.15)$ was significantly greater than the mean score before participation in microfinance program $(M=1.94)$ at $1 \%$ significant level. For item LA10, the mean score for women perception after participation in microfinance program $(\mathrm{M}=2.23)$ was not significantly greater than the mean score before participation in microfinance program $(\mathrm{M}=2.22)$ at $5 \%$ significant level.

For factor 'Legal Awareness' the mean score for women perception after participation in microfinance program $(M=2.17)$ was significantly greater than the mean score before participation in microfinance 
Citation: Sujatha Gangadhar CH, Malyadri P (2015) Impact of Microfinance on Women Empowerment: An Empirical Evidence from Andhra Pradesh. J Entrepren Organiz Manag 4: 141. doi:10.4172/2169-026X.1000141

Page 5 of 8

\begin{tabular}{|l|c|c|}
\hline \multicolumn{2}{|c|}{ Kaiser-Meyer-Olkin Measure of Sampling Adequacy } & .707 \\
\hline Bartlett's Test of Sphericity & Approx. Chi-Square & $1407.41^{\star *}$ \\
\hline 105 & Df & .000 \\
\hline
\end{tabular}

${ }^{* *} p<0.01$

Table 2: KMO and Bartlett's Test Results for Women Empowerment Scale

\begin{tabular}{|c|c|c|c|c|c|c|c|c|c|}
\hline \multicolumn{2}{|c|}{ Factor 1} & \multicolumn{2}{|c|}{ Factor 2} & \multicolumn{2}{|c|}{ Factor 3} & \multicolumn{2}{|c|}{ Factor 4} & \multicolumn{2}{|c|}{ Factor 5} \\
\hline \multicolumn{2}{|c|}{$\begin{array}{c}\text { Household Economic Decision } \\
\text { Making (HED) }\end{array}$} & \multicolumn{2}{|c|}{ Legal Awareness (LA) } & \multicolumn{2}{|c|}{ Mobility (M) } & \multicolumn{2}{|c|}{ Economic Security (ES) } & \multicolumn{2}{|c|}{ Family Decision Making (FD) } \\
\hline Variable & Loading & Variable & loading & Variable & Loading & Variable & Loading & Variable & Loading \\
\hline $\begin{array}{l}\text { HED7 } \\
\text { HED4 } \\
\text { HED5 } \\
\text { HED6 }\end{array}$ & $\begin{array}{l}.895 \\
.877 \\
.865 \\
.811\end{array}$ & $\begin{array}{l}\text { LA8 } \\
\text { LA10 } \\
\text { LA9 }\end{array}$ & $\begin{array}{l}.890 \\
.856 \\
.853\end{array}$ & $\begin{array}{l}\text { M11 } \\
\text { M13 } \\
\text { M12 }\end{array}$ & $\begin{array}{l}.889 \\
.755 \\
.734\end{array}$ & $\begin{array}{l}\text { ES2 } \\
\text { ES1 } \\
\text { ES3 }\end{array}$ & $\begin{array}{l}.806 \\
.783 \\
.736\end{array}$ & $\begin{array}{l}\text { FD14 } \\
\text { FD15 }\end{array}$ & $\begin{array}{l}.845 \\
.843\end{array}$ \\
\hline Eigen Value & 3.7 & \multicolumn{2}{|c|}{2.6} & \multicolumn{2}{|c|}{1.8} & \multicolumn{2}{|c|}{1.4} & \multicolumn{2}{|c|}{1.2} \\
\hline $\begin{array}{l}\text { Percent of } \\
\text { Variance }\end{array}$ & 20.57 & \multicolumn{2}{|c|}{16.43} & \multicolumn{2}{|c|}{13.37} & \multicolumn{2}{|c|}{13.01} & \multicolumn{2}{|c|}{9.94} \\
\hline Total Variance & \multicolumn{9}{|c|}{73.34} \\
\hline
\end{tabular}

Table 3: Factors of Women Empowerment

\begin{tabular}{|c|c|c|}
\hline Factor & Variables & Cronbach alpha \\
\hline Household Economic Decision Making & HED7, HED4, HED5, HED6 & .89 \\
\hline Mobility & M11, M13, M12 & .73 \\
\hline Legal Awareness & LA8, LA10, LA9 & .86 \\
\hline Family Decision making & FD14, FD15 & .62 \\
\hline Economic Security & ES2, ES1, ES3 & .70 \\
\hline
\end{tabular}

Table 4: Reliability Analysis Results

\begin{tabular}{|c|c|c|c|c|c|}
\hline & & Mean & $\mathbf{N}$ & Std. Deviation & Std. Error Mean \\
\hline \multirow{2}{*}{ Pair 1} & FD14-A & 2.23 & 215 & .529 & .036 \\
\hline & FD14-B & 1.73 & 215 & .666 & .045 \\
\hline \multirow{2}{*}{ Pair 2} & FD15-A & 2.37 & 215 & .573 & .039 \\
\hline & FD15-B & 2.16 & 215 & .591 & .040 \\
\hline \multirow{2}{*}{ Pair 3} & FD-A & 2.30 & 215 & .470 & .032 \\
\hline & FD-B & 1.94 & 215 & .468 & .031 \\
\hline
\end{tabular}

A - After participation in MF programme

$\mathrm{B}$ - Before participation in MF programme

Table 5: Paired Sample Statistics for Family Decision Making (FD)

\begin{tabular}{|c|c|c|c|c|c|c|c|c|}
\hline & \multicolumn{5}{|c|}{ Paired Differences } & \multirow{3}{*}{$\mathbf{T}$} & \multirow{3}{*}{ df } & \multirow{3}{*}{$p$ value } \\
\hline & \multirow[t]{2}{*}{ Mean } & \multirow[t]{2}{*}{ Std. Deviation } & \multirow{2}{*}{ Std. Error Mean } & \multicolumn{2}{|c|}{$\begin{array}{l}\text { 95\% Confidence Interval of the } \\
\text { Difference }\end{array}$} & & & \\
\hline & & & & Lower & Upper & & & \\
\hline FD14-A - FD14-B & .502 & .791 & .054 & .396 & .609 & $9.31^{* *}$ & 214 & .000 \\
\hline FD15-A - FD15-B & .214 & .454 & .031 & .153 & .275 & $6.90^{\star *}$ & 214 & .000 \\
\hline FD-A - FD-B & .358 & .480 & .032 & .422 & .293 & $10.92^{* *}$ & 214 & .000 \\
\hline
\end{tabular}

${ }^{* *} p<0.01$

A - After participation in MF programme

$\mathrm{B}$ - Before participation in MF programme

Table 6: Paired Samples Test for Family Decision Making (FD)

\begin{tabular}{|c|c|c|c|c|c|}
\hline & & Mean & $\mathbf{N}$ & Std. Deviation & Std. Error Mean \\
\hline \multirow{2}{*}{ Pair 1} & ES1-A & 2.43 & 215 & .591 & .040 \\
\hline & ES1-B & 2.41 & 215 & .589 & .040 \\
\hline \multirow{2}{*}{ Pair 2} & ES2-A & 2.33 & 215 & .578 & .039 \\
\hline & ES2-B & 1.98 & 215 & .676 & .046 \\
\hline \multirow{2}{*}{ Pair 3} & ES3-A & 2.45 & 215 & .585 & .040 \\
\hline & ES3-B & 2.00 & 215 & .758 & .052 \\
\hline \multirow{2}{*}{ Pair 4} & ES-A & 2.40 & 215 & .464 & .031 \\
\hline & ES-B & 2.12 & 215 & .456 & .031 \\
\hline
\end{tabular}

A - After participation in MF programme

$\mathrm{B}$ - Before participation in MF programme

Table 7: Paired Sample Statistics for Economic Security (ES) 


\begin{tabular}{|c|c|c|c|c|c|c|c|c|}
\hline & \multicolumn{5}{|c|}{ Paired Differences } & \multirow{3}{*}{$\mathbf{T}$} & \multirow{3}{*}{ Df } & \multirow{3}{*}{$p$ value } \\
\hline & \multirow[t]{2}{*}{ Mean } & \multirow{2}{*}{ Std. Deviation } & \multirow{2}{*}{ Std. Error Mean } & \multicolumn{2}{|c|}{$\begin{array}{l}\text { 95\% Confidence Interval of the } \\
\text { Difference }\end{array}$} & & & \\
\hline & & & & Lower & Upper & & & \\
\hline ES1-A - ES1-B & .014 & .118 & .008 & -.002 & .030 & 1.74 & 214 & .083 \\
\hline ES2-A - ES2-B & .349 & .630 & .043 & .264 & .433 & $8.12^{* *}$ & 214 & .000 \\
\hline ES3-A - ES3-B & .456 & .765 & .052 & .353 & .559 & $8.73^{* *}$ & 214 & .000 \\
\hline ES-A - ES-B & .277 & .344 & .023 & .323 & .231 & $11.82^{* *}$ & 214 & .000 \\
\hline
\end{tabular}

${ }^{* *} p<0.01$

A - After participation in MF programme

$\mathrm{B}$ - Before participation in MF programme

Table 8: Paired Samples Test for Economic Security

\begin{tabular}{|c|c|c|c|c|c|}
\hline & & Mean & $\mathbf{N}$ & Std. Deviation & Std. Error Mean \\
\hline \multirow{2}{*}{ Pair 1} & LA8-A & 2.15 & 215 & .572 & .039 \\
\hline & LA8-B & 1.93 & 215 & .611 & .042 \\
\hline \multirow{2}{*}{ Pair 2} & LA9-A & 2.15 & 215 & .577 & .039 \\
\hline & LA9-B & 1.94 & 215 & .612 & .042 \\
\hline \multirow{2}{*}{ Pair 3} & LA10-A & 2.23 & 215 & .573 & .039 \\
\hline & LA10-B & 2.22 & 215 & .591 & .040 \\
\hline \multirow{2}{*}{ Pair 4} & LA-A & 2.17 & 215 & .510 & .034 \\
\hline & LA-B & 2.01 & 215 & .456 & .031 \\
\hline
\end{tabular}

A - After participation in MF programme

$\mathrm{B}$ - Before participation in MF programme

Table 9: Paired Sample Statistics for Legal Awareness (LA)

program $(M=2.01)$ at $1 \%$ significant level. Therefore hypothesis is selected which states that "participation in micro-financing program improves legal awareness". Hypotheses are selected for items LA8 and LA9 but hypothesis is not selected for item LA10. This item is "I know that I can legally divorce my husband, if necessary". It is possible that women did not want to speak about this issue or were not aware of the option of divorce and gave same opinion for this item before and after participation in microfinance program. These microfinance programs lead to legal awareness when combined with participation in workshops and seminars. According to Al-Mamun et al. [29], microcredit program provide a platform to share ideas and knowledge about legal rights and this helps women in improving their understanding of various legal issues.

Paired Samples $\mathbf{t}$ test results for Mobility (M): Paired sample $t$ test results for factor 'Mobility' are shown in Tables 11 and 12. The paired sample $t$ test analysis indicates that for item M11, the mean score of women perception after participation in microfinance program $(M=2.53)$ was significantly greater than the mean score before participation in microfinance program $(\mathrm{M}=2.13)$ at $1 \%$ significant level. For item M12, the mean score for women perception after participation in microfinance program $(M=2.46)$ was significantly greater than the mean score before participation in microfinance program $(\mathrm{M}=2.21)$ at $1 \%$ significant level. For item M13, the mean score for women perception after participation in microfinance program $(\mathrm{M}=2.43)$ was significantly greater than the mean score before participation in microfinance program $(\mathrm{M}=2.19)$ at $1 \%$ significant level.

For factor 'Mobility' the mean score for women perception after participation in microfinance program $(M=2.47)$ was significantly greater than the mean score before participation in microfinance program $(M=2.17)$ at $1 \%$ significant level. This result supports in accepting hypothesis that "participation in micro-financing program improves mobility". This result is in congruence with previous research findings.

According to Le and Raven [18], microfinance helps women in creating upward mobility, but with little impact. When women start participating in microfinance program their mobility increases and develop confidence in going alone outside home. Another study by Pitt et al. [28] found that participation in microcredit programs help women to have greater freedom of mobility.

Paired samples $\mathbf{t}$ test results for Household Economic Decision Making (HED): Paired sample $t$ test results for factor 'Household Economic Decision Making' are shown in Tables 13 and 14. The paired sample $t$ test analysis indicates that for item HED4, the mean score of women perception after participation in microfinance program $(M=2.43)$ was significantly greater than the mean score before participation in microfinance program $(M=2.28)$ at $1 \%$ significant level. For item HED5, the mean score for women perception after participation in microfinance program $(M=2.34)$ was significantly greater than the mean score before participation in microfinance program $(M=1.99)$ at $1 \%$ significant level. For item HED6, the mean score for women perception after participation in microfinance program $(M=2.33)$ was significantly greater than the mean score before participation in microfinance program $(M=2.29)$ at $1 \%$ significant level. For item HED7, the mean score for women perception after participation in microfinance program $(\mathrm{M}=2.38)$ was not significantly greater than the mean score before participation in microfinance program $(M=2.37)$ at $5 \%$ significant level.

For factor 'Household Economic Decision Making' the mean score for women perception after participation in microfinance program $(\mathrm{M}=2.37)$ was significantly greater than the mean score before participation in microfinance program $(M=2.20)$ at $1 \%$ significant level. This result supports in accepting hypothesis that "participation in micro-financing program improves Household Economic Decision Making". However, this hypothesis is accepted for items HED4, HED5 (at 1\% significant level) and HED6 (at 5\% significant level) but not for item HED7. This item states that "I can buy clothes or other essentials for myself without permission of my husband". Participation in microfinance programs improve women household economic decision making but before purchase of any 
Citation: Sujatha Gangadhar CH, Malyadri P (2015) Impact of Microfinance on Women Empowerment: An Empirical Evidence from Andhra Pradesh. J Entrepren Organiz Manag 4: 141. doi:10.4172/2169-026X.1000141

Page 7 of 8

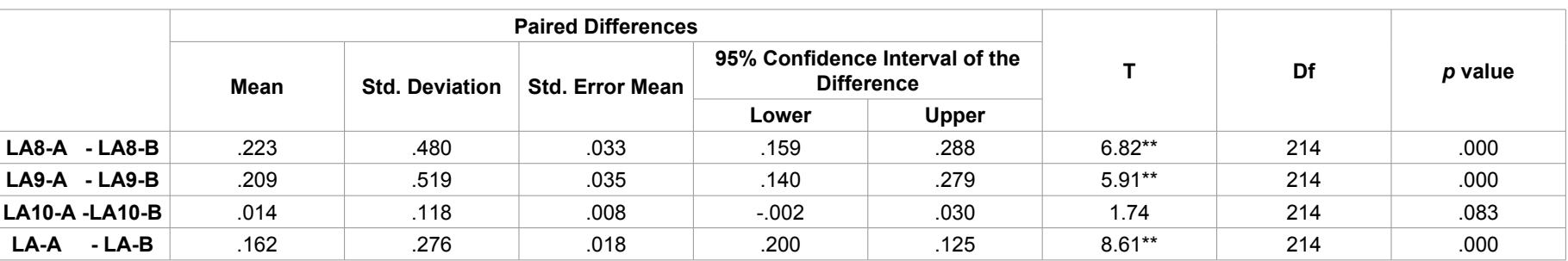

** $p<0.01$

A - After participation in MF programme

$\mathrm{B}$ - Before participation in MF programme

Table 10: Paired Samples Test for Legal Awareness

\begin{tabular}{|c|c|c|c|c|c|}
\hline & & Mean & $\mathbf{N}$ & Std. Deviation & Std. Error Mean \\
\hline \multirow{2}{*}{ Pair 1} & M11-A & 2.53 & 215 & .578 & .039 \\
\hline & M11-B & 2.13 & 215 & .849 & .058 \\
\hline \multirow{2}{*}{ Pair 2} & M12-A & 2.46 & 215 & .544 & .037 \\
\hline & M12-B & 2.21 & 215 & .748 & .051 \\
\hline \multirow{2}{*}{ Pair 3} & M13-A & 2.43 & 215 & .614 & .042 \\
\hline & M13-B & 2.19 & 215 & .793 & .054 \\
\hline \multirow{2}{*}{ Pair 4} & M-A & 2.47 & 215 & .467 & .031 \\
\hline & M-B & 2.17 & 215 & .540 & .036 \\
\hline
\end{tabular}

A - After participation in MF programme

$\mathrm{B}$ - Before participation in MF programme

Table 11: Paired Sample Statistics for Mobility (M)

\begin{tabular}{|c|c|c|c|c|c|c|c|c|}
\hline & \multicolumn{5}{|c|}{ Paired Differences } & \multirow{3}{*}{$\mathbf{T}$} & \multirow{3}{*}{ df } & \multirow{3}{*}{$p$ value } \\
\hline & \multirow[t]{2}{*}{ Mean } & \multirow[t]{2}{*}{ Std. Deviation } & \multirow[t]{2}{*}{ Std. Error Mean } & \multicolumn{2}{|c|}{$\begin{array}{l}\text { 95\% Confidence Interval of the } \\
\text { Difference }\end{array}$} & & & \\
\hline & & & & Lower & Upper & & & \\
\hline M11-A - M11-B & .400 & .754 & .051 & .299 & .501 & $7.78^{* *}$ & 214 & .000 \\
\hline M12-A - M12-B & .251 & .574 & .039 & .174 & .328 & $6.41^{* \star}$ & 214 & .000 \\
\hline M13-A - M13-B & .242 & .570 & .039 & .165 & .318 & $6.22^{* \star}$ & 214 & .000 \\
\hline$M-A-M-B$ & .297 & .377 & .025 & .348 & .246 & $11.56^{* *}$ & 214 & .000 \\
\hline
\end{tabular}

** $p<0.01$

A - After participation in MF programme

$\mathrm{B}$ - Before participation in MF programme

Table 12: Paired Samples Test for Mobility

\begin{tabular}{|c|c|c|c|c|c|}
\hline & & Mean & $\mathbf{N}$ & Std. Deviation & Std. Error Mean \\
\hline \multirow{2}{*}{ Pair 1} & HED4-A & 2.43 & 215 & .606 & .041 \\
\hline & HED4-B & 2.28 & 215 & .715 & .049 \\
\hline \multirow{2}{*}{ Pair 2} & HED5-A & 2.34 & 215 & .628 & .043 \\
\hline & HED5-B & 1.99 & 215 & .791 & .054 \\
\hline \multirow{2}{*}{ Pair 3} & HED6-A & 2.33 & 215 & .611 & .042 \\
\hline & HED6-B & 2.29 & 215 & .649 & .044 \\
\hline \multirow{2}{*}{ Pair 4} & HED7-A & 2.38 & 215 & .622 & .042 \\
\hline & HED7-B & 2.37 & 215 & .635 & .043 \\
\hline \multirow{2}{*}{ Pair 5} & HED-A & 2.37 & 215 & .538 & .036 \\
\hline & HED-B & 2.20 & 215 & .513 & .035 \\
\hline
\end{tabular}

A - After participation in MF programme

B - Before participation in MF programme

Table 13: Paired Sample Statistics for Household Economic Decision Making (HED)

item they have to take permission of their husbands. Sultana and Hasan (2010) revealed that women have better economic position after joining microfinance program. Improved economic position fosters women's household economic decision making.

\section{Conclusion}

Empowering women is the main social objective of microfinance programs. It is difficult to evaluate the effectiveness of microfinance program on women empowerment because measurement of women empowerment is a difficult task. In most of the studies women empowerment is measured as latent variable. This study also measures women empowerment as latent variable.

The findings of this study revealed that microfinance is a powerful tool in enhancing women empowerment for its all indicators like household economic decision making, economic security, family 


\begin{tabular}{|c|c|c|c|c|c|c|c|c|}
\hline & \multicolumn{5}{|c|}{ Paired Differences } & \multirow{3}{*}{$\mathbf{T}$} & \multirow{3}{*}{ df } & \multirow{3}{*}{$p$ value } \\
\hline & \multirow[t]{2}{*}{ Mean } & \multirow{2}{*}{ Std. Deviation } & \multirow{2}{*}{ Std. Error Mean } & \multicolumn{2}{|c|}{$\begin{array}{l}\text { 95\% Confidence Interval of the } \\
\text { Difference }\end{array}$} & & & \\
\hline & & & & Lower & Upper & & & \\
\hline HED4-A - HED4-B & .149 & .449 & .031 & .088 & .209 & $4.85^{\star \star}$ & 214 & .000 \\
\hline HED5-A - HED5-B & .353 & .714 & .049 & .257 & .449 & $7.25^{* *}$ & 214 & .000 \\
\hline HED6-A - HED6-B & .047 & .251 & .017 & .013 & .080 & $2.71^{*}$ & 214 & .007 \\
\hline HED7-A - HED7-B & .009 & .096 & .007 & -.004 & .022 & 1.41 & 214 & .158 \\
\hline HED-B - HED-A & .174 & .249 & .017 & .207 & .140 & $10.24^{* *}$ & 214 & .000 \\
\hline
\end{tabular}

** $p<0.01$

$* p<0.05$

A- After participation in MF programme

Table 14: Paired Samples Test for Household Economic Decision Making (HED) B -Before participation in MF programme

decision making, mobility and legal awareness. Only participation in microfinance program does not lead to increase in women empowerment but when it is coupled with participation in seminars, workshops and training then it helps women in enhancing their empowerment. These training programs not only provide selfemployment training but also facilitate good decision-making.

All the indicators which have been used to measure women empowerment in this study are not further studied for which indicators are more important in enhancing women empowerment. Future studies may target on this issue. This study is conducted in only one state of India. It opens the door to conduct similar studies in other states of India and in other countries to reflect impact of culture diversity on women empowerment. Demographic variables are considered controlled variables for this study but they have important role in explaining women empowerment. Therefore, future researches should consider role of demographic variables while explaining women empowerment.

\section{References}

1. Srivastava M (2009) Essay on Women Empowerment.

2. Urmila M (2011) Role of Self Help Group Bank Linkage Model in Women Empowerment.Asia Pacific Journal of Research in Business Management 2: 47-65.

3. Suja S (2012) Woman Empowerment Through Self-Help Group-An Evaluative Study. Global Management Review 6: 68-83.

4. Srabanti M, Proloy P (2011) A Planned Model for a Sustainable Self-Help Group in West Bengal-An Analytic Hierarchical Process Approach. Vilakshan: The XIMB Journal of Managementm 7: 85-98.

5. Elahi KQI (2003) Microfinance, Empowerment, and Sudra Women in India Development in Practice 13: 570-572.

6. Kabeer N (1999) Resources, Agency, Achievements: Reflections on the Measurement of Women's Empowerment. Development and Change 30: 435-464.

7. Banu D, Farashuddin F, Hossain A, Akter S (2001) Empowering Women in Rural Bangladesh: Impact of Bangladesh Rural Advancement Committee's (BRAC's) Programme. Journal of international women's studies2: 30-53.

8. Otero M (1999) Bringing Development Back into Microfinance. Journal of Microfinance 1: 8-19.

9. Schreiner M, Colombet HH (2001) From Urban to Rural: Lessons for Microfinance from Argentina. Development Policy Review 19: 339-354.

10. Ledgerwood J (1999) Sustainable Banking with the Poor. The World Bank, Microfinance Handbook: an Institutional and Financial Perspective.

11. Robinson M (2002) The Microfinance Revolution: Volume 2. Lessons from Indonesia. World Bank Group: Open Knowledge Repository.

12. Goetz AM, Gupta RS (1996) Who takes the credit? Gender, power, and contro over loan use in rural credit programs in Bangladesh. World development 24 : 45-63.

13. Hashemi SM, Schuler SR, Riley AP (1996) Rural Credit Programs and women's empowerment in Bangladesh. World Development 24: 635-653.
14. Sarumathi S, Mohan K (2011) Role of Micro Finance in Women's Empowerment (An Empirical study in Pondicherry region rural SHG's). Journal of Management and Science 1: 1- 8.

15. King EM (2008) Vietnam's Decree on Microfinance: A Flawed Attempt to Create an Enabling Legal Environment for Microfinance. Pacific Rim Law \& Policy Journal 17: 187-207

16. Swain RB, Nguyen VS (2008) Microfinance and Poverty Reduction in the Mekong Delta in Vietnam. African and Asian Studies17:191-215.

17. Malathi S, Vijayarani K (2012) Microfinance and Women Empowerment in the Rural Areas of Cuddalore District of Tamilnadu.Language in India 12: 174 -182.

18. Le QV, Raven PV (2015) Woman entrepreneurship in rural Vietnam: success and motivational factors. The Journal of Developing Areas 49: 57-76.

19. Sanyal P (2009) From Credit to Collective Action: The Role of Microfinance in Promoting Women's Social Capital and Normative Influence. American Socialogical Review 74: 529-550.

20. Hussain AKMG, Nargis N (2008) A Welfare Economic Analysis of the Impact of Microfinance in Bangladesh, Nilkhet, Dhaka-1000, Bangladesh.

21. Holvoet N (2005) Thelmpact of Microfinance on Decision-Making Agency: Evidence from South India. Development and Change 36: 75-102.

22. Naved RT (1994) Empowerment of Women: Listening to the Voices of Women The Bangladesh Development Studies, Women, Development and Change 22 121-178.

23. Mahmud S (2003) Actually how Empowering is Microcredit? Development and Change 34: 577-605.

24. Aruna M, Jyothirmayi R (2011) The role of microfinance in women empowerment; A study on the SHG Bank Linkage Program in Hyderabad (Andhra Pradesh). Indian Journal of Commerce and Management Studies 2 : $77-95$

25. Sultana S, Hasan SS (2010) Impact of Micro-credit on Economic Empowermen of Rural Women. The Agriculturists 8: 43-49.

26. Moyle TL, Dollard M, Biswas SN (2006) Personal and Economic Empowermen in Rural Indian Women: A Self Help Group Approach. International Journal of Rural Management 2: 245-266.

27. Nader YF (2008) Microcredit and the socio-economic wellbeing of women and their families in Cairo. The Journal of Socio-Economics 37: 644-656.

28. Pitt M, Khandker S, Cartwright J (2003) Does Micro-Credit Empower Women? Evidence from Bangladesh. World Bank: Policy Research Working Paper Washington D.C

29. Al-Mamun A, Wahab SA, Mazumder MNH, Su Z (2014) Empirical Investigation on the Impact of Microcredit on Women Empowerment in Urban Peninsular Malaysia. The Journal of Developing Areas 48: 287-306

30. Swain RB, Wallentin FY (2012) Factors empowering women in Indian self-help group programs. International Review of Applied Economics 26: 425-444. 